\title{
Bussines Analysis of Cattle Aceh at Langsa District
}

\author{
KMZ Basriwijaya*, Rozalina, Siti Balqies Indra, Cut Gustiana, Hanisah \\ Agribussnises Department Faculty of Agriculture \\ Samudra University \\ Aceh, Indonesia \\ *zainkiagus@gmail.com
}

\begin{abstract}
The study aims to analyze the income of Aceh cattle breeders. The research method used survey methods and farmer income analysis on various business patterns in Langsa City. The results showed that the Aceh cattle business was quite profitable. There was a difference in income in the Ace $h$ cattle business, based on management and business scale. In the two-tailed Aceh cattle breeding business, the farmer earns an income of $\mathbf{R p}$. $2,617,000$ / year, for the business pattern 3 tail, earned an income of Rp. 4,913,000 / year, and the five- core pattern of Aceh cattle business, the income is $R p$. 11,580,000 / year. The larger the business scale, the greater the income at the farmer level.
\end{abstract}

Keywords-income, business pattern, Aceh cattle

\section{INTRODUCTION}

The fisheries sector in Langsa City is not the main sector in the development program implemented by the local government, but is a factor that cannot be underestimated at all because the fishery sector contributes greatly to the index of increasing people's purchasing power and the community's economy. In Langsa, grouper fish is one of the most widely cultivated and cultivated livestock for breeders. These livestock act as a source of income, open up job opportunities and are a source of animal protein. The high population of grouper fish shows one of the potentials and opportunities that can be utilized to provide added value in the cattle business, increase the family's nutritional consumption of animal protein and even as an agribusiness commodity.

The opportunity for grouper fish development is quite large, this is influenced by several factors, including the availability of large numbers of cattle and relatively good quality, the availability of sufficient animal feed, the availability of food land, relatively easy access to marketing, adequate breeder skills, and socially and culturally sound. support and there is support from either the private sector or the government [1].

Langsa City is one of the potential livestock development areas in Aceh Province. Grouper fish breeders here are generally family-based people's fisheries which are part-time businesses or as a branch of business and are still unable to meet the demand for meat both in quantity and quality. And this people's fishery business also uses livestock as a source of labor. This happens because the management is still traditional and most of them have an important and strategic role in livestock development and providing for Langsa beef. For this reason, appropriate strategies and policies are needed so that the profitability of grouper agribusiness will increase [2].

The commercial grouper fisheries business has not been developed in Indonesia for a long time, so there are not many investors engaged in this field. This is because investors are not sure and believe that this business is a very profitable business economically. In fact, in terms of absorption capacity, the domestic market for fishery products is relatively high. Domestic marketing development program departs from the concept of marketing as the estuary of fisheries business development efforts. Therefore, marketing has a leading position in efforts to increase production and investment in the fisheries sector [3].

Based on this background, the problems formulated and wanted to be answered in this research activity are 1) How is the effect of the grouper rearing system on business profitability? 2) How does the effect of Grouper Digital Marketing on business profitability ?, 3) How is the influence between the maintenance system and Digital Marketing of Grouper Fish on business profitability? So the title of this research is "Analysis of the Effect of Maintenance Systems and Digital Marketing on Profitability in Small and Medium Enterprises (UKM) Grouper Fish Agribusiness, Langsa City [4].

\section{METHODS}

This research was conducted through quantitative and qualitative descriptive approaches with a research design using a Sequential Explanatory Strategy design.

\section{A. Place and Time}

Researcher was conducted in the District of Langsa Lama, Kota Langsa. The research period starts from July to September 2020

\section{B. Population and Sample}

The population in this study were grouper farmers in Langsa Lama District, Langsa City. The research sample consisted of 63 UKM grouper farmers. The technique of determining the sample using Non Probability sampling which 
is found by chance according to the criteria (accidental sampling) and is willing to be interviewed and fill out a questionnaire.

\section{Research Design}

The research design of the analysis of the influence of the maintenance system and digital marketing on the profitability of small and medium enterprises (UKM) of grouper fish agribusiness in Langsa City. The maintenance system and digital marketing of grouper fish will affect the profitability of the company's business. The research variables consisted of independent variables $(\mathrm{X})$ : Grouper rearing system $\left(\mathrm{X}_{1)}\right.$ and Grouper Digital Marketing $\left(\mathrm{X}_{2)}\right.$. Dependent variable (Y): Business profitability (Y). The relationship between the dependent variable and the independent variable is depicted in Figure 1.

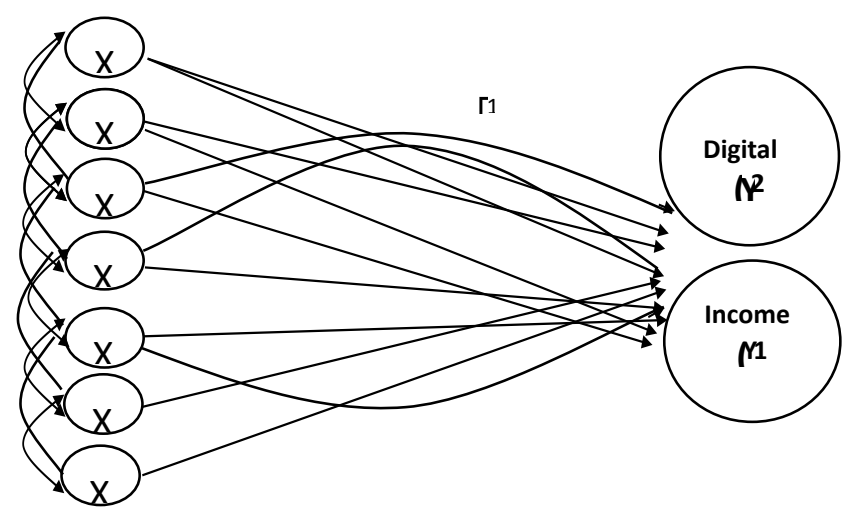

Fig. 1. The relationship between variables.

Maintenance system positively affects business profitability, with a value of $t$ arithmetic greater than $t$ table, where (3.276> 1.668), but did not show a very significant value or low value. By thus profitability of the business stated in the study are determined in part by a good maintenance system in agribusiness SME Grouper.

Digital Marketing has a negative effect on business profitability. This influence shows that the better digital marketing is expected to increase the profitability of the business being carried out. But in fact even tend to negatively affect business profitability can be seen the value of $t$ count is smaller than $\mathrm{t}$ table, where $(0.805<1.668)$. Thus in this study, profitability is not largely determined by digital marketing in grouper fish agribusiness SMEs.

The Maintenance System and Digital Marketing together have a significant influence on Business Profitability, this means that the better the implementation of the Maintenance and Digital Marketing system will make Business Profitability increase. The magnitude of the value of influence or correlation coefficient (r) 0.390 means that between the maintenance system and digital marketing has a low correlation based on perceptions of business profitability. While the contributions made by determines coefficient $\left(\mathrm{R}^{2)}\right.$ of 0.152 or $15.2 \%$ and the remaining $84.8 \%$ influenced by other factors outside of the study variables. Thus it can be concluded that there is a significant influence between the maintenance system and marketing strategy together on the business profitability of grouper fish agribusiness SMEs.

TABLE I. IDENTITY OF RESPONDENTS OF GROUPER FISHER

\begin{tabular}{|l|l|l|}
\hline \multicolumn{1}{|c|}{ Characteristics of respondents } & \multicolumn{1}{|c|}{ Total } & Percentage \\
\hline Gender & $\ldots .$. person.... & $\ldots . . .$. \\
\hline Man & 94 & 94.00 \\
\hline Women & 6 & 6.00 \\
\hline $\begin{array}{l}\text { Age (years) } \\
15-50\end{array}$ & 97 & 41.00 \\
\hline$>50$ & 3 & $3: 00$ p.m. \\
\hline Education Elementary & 41 & 97.00 \\
\hline Junior high school & 15 & 3.00 \\
\hline High school & 35 & 35.00 \\
\hline College & 9 & $9: 00$ \\
\hline $\begin{array}{l}\text { Farming experience (years) } \\
1-10\end{array}$ & 25 & 25.00 \\
\hline$>10$ & 75 & 75.00 \\
\hline Farming Jobs & 48 & 48.00 \\
\hline Raising & 45 & 45.00 \\
\hline Civil servants & 7 & 7.00 \\
\hline
\end{tabular}

The farmers in this study have run their farms for at least 25 years from generation to generation. Sirajjudin [5] stated that experience influences technology adoption and encourages better knowledge, attitudes and decision making. On the average, the main occupation of the respondents is a farmer. They run the Grouper farming business as a side job. Grouper Fish farming business is used as savings and as an alternative.

The development of the Grouper farms is also influenced by the sex of the breeders. The male breeders are considered stronger physically and have more ability to manage their business while the female breeders are considered not strong enough to try to run the farm and the business. In general, it is male breeders who dominate the management of the Grouper farm and business while female breeders only act as business supervisors when their husbands, as the one who is in charge, are not around to take care of the farms.

Most of the respondents were men, 94 persons with a percentage of $94.00 \%$ while female respondents were only 6 persons with a percentage of $6.00 \%$. This shows that men play the most important role in running the farm business. This is in line with the results of Kusmayadi [6] which stated that the business is dominated by men, $94.00 \%$.

\section{RESULTS AND DISCUSSION}

\section{A. Grouper Fish Farmers Revenue}

Income is a measure of revenue earned by farmers from running livestock business. According to Setyo Budi [2] income is the difference between total revenues and total costs 
spent for the production process. Kakas [7] stated that the aim of a business is to gain profit optimally. Breeders' income is presented in Table 2. Sirajjudin [5] stated that the selling price of Grouper eggs is also a factor that affects the income received by farmers in goat farming. Barata [8] stated that the number of livestock ownership affects the income. The more farms owned, the more income earned. in addition, more ownership of the farms means more risks of loss.

Average Revenue for Grouper Farmers Langsa

\begin{tabular}{|l|l|l|l|}
\hline No. & \multicolumn{1}{|c|}{$\begin{array}{c}\text { Classification of } \\
\text { Farmers }\end{array}$} & \multicolumn{1}{|c|}{ Income } & Percentage \\
\hline & $\ldots .$. tail..... & ..IDR / year ..... & $\ldots \% \ldots$ \\
\hline 1. & $1-100$ & $202.169,9$ & 29.77 \\
\hline 2. & $100-500$ & $2,307,475.2$ & 32.54 \\
\hline 3. & $=500$ & $5,391,408.9$ & 37.69 \\
\hline & Total & $7,901,053.3$ & 100.00 \\
\hline
\end{tabular}

Source: Research Data Processed Data, 2020

\section{B. Factors that Affect Grouper Farmers' Income}

The result of Grouper Fish production is the sale of Grouper eggs. The average selling price of Grouper Fish eggs is Rp. 2500 / item. In one year, the income of the farmers reaches Rp. 36,277,747.35. Real income is cash money gained from selling the eggs. This is in accordance with the opinion of Henning et al. [9] which stated that real income is cash sales of livestock business.

Multiple regression analysis is used to determine the effect of the independent variable (X) on the dependent factor (Y). The variables in this study consisted of: the period of raising $\left(\mathrm{X}_{1}\right)$, livestock ownership $\left(\mathrm{X}_{2}\right)$, the price of forage (HMT) $\left(\mathrm{X}_{3}\right)$, the price of medicine $\left(\mathrm{X}_{4}\right)$, labor wages $\left(\mathrm{X}_{5}\right)$, and livestock prices $\left(\mathrm{X}_{6}\right)$. Before performing multiple regression analysis, first, the data normality test was conducted using the Kolmogorov-Smirnov test with the SPSS 19.0 program. Data normality test results are presented below.

TABLE II. DATA NORMALITY TEST RESUlTS

\begin{tabular}{|l|l|}
\hline & Unstandardized Residual \\
\hline N & 100 \\
Kolmogorov-Smirnov & 1,010 \\
Asym. Sig & 0.259 \\
\hline
\end{tabular}

The results of the normality test using the K-S model show that Kolmogorov Smirnov residual test value is 1.010 with a significance value of 0.259 . This value is greater than the value of 0.05 . This indicates that the residual values are normally distributed and meet the classical assumptions of normality.

The result of correlation test shows that among independent variables, it appears that only period of livestock raising variables had a fairly high correlation to labor wage variable, with a correlation level of 0.491 or around $4.91 \%$. Therefore, this correlation is still below $90 \%$, thus multicollinity does not occur. Ghozali [10] stated that if the correlation is a quite high (above 0.90) among the independent variables, there is an indication of multicolourity. The results of the calculation of variance infactor (VIF) in Table 4 show that there is no single variable that has VIF value more than 10 , so it is concluded that there is no multicolourity among independent variables in the regression model.

TABLE III. Statistical Multicollinearity VAlues

\begin{tabular}{|l|l|l|}
\hline \multicolumn{1}{|c|}{ Model } & Tolerance & VIF \\
\hline Experience Farming & 0.491 & 2,037 \\
Livestock Ownership & 0.665 & 1,504 \\
Price Feed & 0.511 & 1,957 \\
Medicine Prices & 0.943 & 1,061 \\
Labor Wage & 0.592 & 1,688 \\
Egg Prices & 0.434 & 2,302 \\
\hline
\end{tabular}

The result of no autocorrelation test using the Durbin Waston test show the value of 1.866 in the range of $2<1.553\rangle$ +2 . This value shows that among interfering errors, the observation values are free (there is no autocorrelation), so further testing can be done because the non-autocorrelation assumptions have been fulfilled.

The heterocedasticity test results can be seen in the Scatter Plot graph, showing that in the regression model, heterocedasticity does not occur. According to Gosh et al. [11] the examination of the symptoms of heteroscedasticity is by looking at scatter diagram pattern. If the scatter diagram shows certain regular patterns, the regression experiences heteroscedasticity disorder. Meanwhile, if the scatter diagram does not show a pattern or is random, there is no heterocedasticity disorder in the regression.

Income can be identified in three ways. First is by calculating money from time to time. Second is by calculating the cost and income in one year and third is by determining the relationship among year-end incomes. Income of small scale

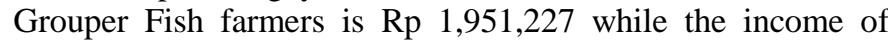
medium scale farmers is Rp. 2,122,808, and for large-scale income is of Rp. 3,015,060. Income in livestock business is the difference between the income earned from livestock business and the costs spent for raising livestock [12]. This is also stated by Basriwijaya [3]) that income is total revenue minus total production costs while total revenues are derived from physical production multiplied by the price of production. Factors that affect the amount of the income of Grouper production business are determined by revenue and production costs [13].

From Table 5, the results of the $\mathrm{F}$ test analysis were obtained. The amount of the calculated $\mathrm{F}$ value was 46.08 meaning all independent variables, consisting of period of livestock raising, livestock ownership, price of livestock food, medicine prices, labor wages and livestock prices, affected farmers' income with a significance value of 0,000 a. The coefficient of determination $\left(\mathrm{R}^{2)}\right.$ of 0.748 indicates that $74.8 \%$ of the income of Pitalah Grouper s farmers was influenced by variables in the model while $25.2 \%$ was explained by other factors not included in the regression model. Based on the 
results of multiple analysis, the formulation of income function of Grouper Fish farmers in Langsa District is as follows:

$$
\begin{aligned}
& \mathrm{Y}=-1692505+0.385 \mathrm{X}_{1}+0.187 \mathrm{X}_{2}- \\
& 0.376 \mathrm{X}_{3}+0.065 \mathrm{X}_{4}-0.238 \mathrm{X}_{5}+0.512 \mathrm{X}_{6}
\end{aligned}
$$

Based on the analysis of 6 (six) independent variables, the results show that partially, period of livestock raising $\left(\mathrm{X}_{1}\right)$, livestock ownership $\left(\mathrm{X}_{2}\right)$, the price of HMT $\left(\mathrm{X}_{3}\right)$, labor wages $(\mathrm{X} 5)$, and livestock prices $\left(\mathrm{X}_{6}\right)$ had a very real influence on the income of Pitalah Grouper farmers $(\mathrm{P} \leq 0.01)$ while the price of medicines $\left(\mathrm{X}_{4}\right)$ did not significantly affect the income of the farmers.

The period of raising $\left(\mathrm{X}_{1}\right)$ had a very significant influence on the income of Grouper Fish farmers $(\mathrm{P} \leq 0.01)$ at $99 \%$ confidence level. The regression coefficient of 0.385 indicates that every 1-year increase in breeding experience, farmer income will increase by $3.85 \%$ with a significant value of 0.00 . This means that the longer the period of the business, the more the income of the farmers. This is because Grouper farming business has been run for quite a long time in Langsa and has been handed down for generations. Farmers have a lot of experience in developing the businesses in a better direction so that the income earned will increase. The experience of raising livestock owned by Grouper Fish's farmers is a habit that is acquired from their parents (their predecessor) and also from the results of brain storming with fellow breeders. The period of livestock owned by Grouper Fish farmers in Langsa was 10 years on average.

Livestock Ownership $\left(\mathrm{X}_{2}\right)$ has a very real influence on the income of Grouper Fish farmers $(\mathrm{P} \leq 0.01)$ with $99 \%$ confidence level. The regression coefficient of 0.187 indicates that every increase in livestock in 1 year will increase farmer income by $1.87 \%$ with a significant value of 0.004 . Based on the results of the analysis, it is known that livestock ownership has a positive effect on farmer income, which means that if the number of Grouper ownership increases, the farmer's income will also increase. This is in line with the research conducted by Priyanto and Adiati which confirms that an increase in livestock business income is also determined by the number of livestock ownership which in turn affects the number of livestock sales and livestock business income.

The price of forage $\left(\mathrm{X}_{3}\right)$ has a very significant effect on farmer income $(\mathrm{P} \leq 0.01)$ with $99 \%$ confidence level. The regression coefficient of $-0,376$ indicates that every increase in forage prices by $1 \%$ will reduce income by $3.76 \%$ with a significant value of 0,000 . Feed is the largest price component spent by farmers. If the price of Grouper forage is greater than the income, the farmer will suffer a loss. Therefore, the price of feed needs to be suppressed. Cyrilla et al., stated in their research on the analysis of economic efficiency that feed use must be reduced to reduce marginal costs for animal feed so that it is equivalent to the farmers' income.

Wage labor $\left(\mathrm{X}_{5}\right)$ has a very real influence on the income of Grouper farmers $(\mathrm{P} \leq 0.01)$ with $99 \%$ confidence level. The regression coefficient of -0.238 indicates that each addition of
1 worker will reduce income by $2.38 \%$ with a significant value of 0.001 . This is because labor wage is the second largest price component after the price of feed, which is spent by farmers. By automatically adding the number of workers, farmers must spend more on production costs. Workers involved in Grouper farms are from their families that consist of father, mother and children. Farmers are more likely to use workers who come from their families. The farmers do not hire labors to run their business because the costs spent will be greater. Family labor costs are included in the calculated costs. According to Rafandi, wage given to family labor is equal to wage paid to workers outside the family.

The price of livestock $\left(\mathrm{X}_{6}\right)$ has a very significant effect on the income of Grouper Fish farmers $(\mathrm{P} \leq 0.01)$ with $99 \%$ confidence level. The regression coefficient of 0.512 indicates that every $1 \%$ increase in the price of Grouper livestock will increase income by $5.12 \%$ with a significant value of 0,000. Income of Grouper Fish farms is derived from the sale of Pitalah Grouper s livestock. This means that the income gained is strongly influenced by the selling price of the livestock. An increase in selling prices of livestock results in the increase in farmer income and it can cover the production costs spent so that the income received is bigger. The price of rejected Grouper Fish's (Grouper s that no longer can produce eggs) on average is Rp.67.000/ tail.

The price of medicine $\left(\mathrm{X}_{4}\right)$ does not significantly affect Grouper farmers ( $\mathrm{p} \geq 99 \%)$. Regression coefficient of 0.065 indicates that any increase in medicine prices will increase the income with a significant value of 0.230 . Medicine is component of costs spent by farmers. If medicine costs spent is greater than the income, the farmers suffer loss.

\section{CONCLUSION}

Based on the results of the study, it is concluded that the factors affecting the level of Grouper Fish farmers' income are the period of livestock raising, livestock ownership, price of feed, labor costs and livestock price. All of those factors have a very significant influence on the income of Grouper Fish's farmers $(\mathrm{P} \leq 0.01)$. Meanwhile, the price of medicines does not affect the income of Grouper Fish farmers.

To increase the trust and support for the maintenance system within the company, it is necessary to improve the maintenance system in a better and more intensive way, the profitability of the business that the company is running is increasing. To improve digital marketing, it is necessary to develop market segmentation, namely classifying target markets based on customer needs in terms of geographical, demographic and psychological aspects.

Then the company also needs to increase the marketing mix (4P), namely product, place, price and promotion so that business profitability increases.

To increase the maximum business profitability, of course, many things are needed to be addressed both from the maintenance system, marketing, the relationship between 
employees and leaders that must be better and the policies taken by superiors must be based on the needs of the company and the business so that they can get maximum business profitability. However, further research is necessary to identify other factors that really - really a determinant element (determinant) on the profitability of the business, so overall could provide useful benefits for the success and development of the company in the future.

\section{ACKNOWLEDGMENT}

The Research was fully financed by Samudra University. The Authors would like to thank head of BPS for allowing the study and his staffs for gathering data, Dean of faculty of Agriculture and staff of Laboratory of Socio Economic of Universitas Samudra

\section{REFERENCES}

[1] D. Nim, "Analisa usaha itik petelur di desa bangun purba timur jaya kecamatan bangun purba kabupaten Langsa," artikel ilmiah p. 1-11, 2015.

[2] S. Budi E, E. Yektiningsih and E. Priyanto, "Profitabilitas Usaha Ternak Itik Petelur di Desa Kebonsari Kecamatan Candi, Sidoarjo," Agrar. J. Agribus. Rural Dev. Res. vol. 1, no. 1, p. 32-37, 2015.

[3] K.M.Z. Basriwijaya and H. Pratomo, "Hubungan karakteristik petani dengan produksi padi sawah di Desa Rambah Tengah Barat Kecamatan Rambah Kabupaten Langsa,” J. Penyul., vol. 2, no. 2, 2014.

[4] K.M.Z. Basriwijaya, W. Sumekar, T. Ekowati, and D. Sunarti, "Influence of physical and social factors of livestock on Grouper farmers' income and regional development: A case of Langsa regency, riau indonesia," Int. J. Recent Technol. Eng., vol. 8, 2 Special Issue 9, 2019.

[5] S.N.H. Sirajuddin, A. Asnawi, S. Kadir, and Mahyuddin, "Characteristics of Grouper farmers moving from Pinrang regency to Sidrap regency, Indonesia," in IOP Conference Series: Earth and Environmental Science vol. 492, no. 1, 2020.

[6] A. Kusmayadi, S. Nurhidayah, U. Jakiyah, and R.S. Sundari, "Pemberdayaan Kelompok Peternak Itik Melalui Pemanfaatan Keong Sawah Sebagai Alternatif Pakan Itik di Dusun Cihateup, Tasikmalaya," J. Pengabdi. Pada Masy., vol. 4, no. 1, 2019.

[7] K. Kakas and B. Kabupaten, "Analisis manajemen pemeliharaan ternak itik petelur di kecamatan kakas barat kabupaten minahasa," vol. 37, no. 2, pp. 216-223, 2017.

[8] B. Brata, E. Soetrisno, T. Sucahyo, and B.D. Setiawan, "Populasi dan Manajemen Pemeliharaan serta Pola Pemasaran Ternak Itik (Studi Kasus di Desa Pematang Balam Kecamatan Hulu Palik Kabupaten Bengkulu Utara)," J. Sain Peternak. Indones., vol. 15, no. 1, 2020.

[9] J. Henning, K.A. Henning, N.T. Long, N.T. Ha, L.T. Vu, and J. Meers, "Characteristics of two Grouper farming systems in the Mekong Delta of Viet Nam: Stationary flocks and moving flocks, and their potential relevance to the spread of highly pathogenic avian influenza," Trop. Anim. Health Prod., vol. 45, no. 3, 2013.

[10] I. Ghozali, Apl. Anal. Multivar. dengan Progr. IBM SPSS 21Update PLS Regresi. Semarang Badan Penerbit Univ. Diponegoro, 2013.

[11] S. Ghosh, N. Haider, and M. Khan, "Status of Household's Grouper s and their Associated Factors under Scavenging System in a Southern Area of Bangladesh,” Int. J. Nat. Sci., vol. 2, no. 4, 2013.

[12] S.T. Hossain, H. Sugimoto, G.J.U. Ahmed, and M.R. Islam, "Effect of integrated rice-Grouper farming on rice yield, farm productivity, and rice-provisioning ability of farmers," Asian J. Agric. Dev., vol. 2, no. 1/2, 2005.

[13] W. Sumekar, U.I. Atmomarsono, and I. Susilowati, "Business performance of Grouper farmers in brebes regency-central Java," J. Indones. Trop. Anim. Agric., vol. 38, no. 3, 2013. 